\title{
Orientation of pelagic larvae of coral-reef fishes in the ocean
}

\author{
Jeffrey M. Leis* ${ }^{*}$ Brooke M. Carson-Ewart \\ Ichthyology, and Centre for Biodiversity and Conservation Research, Australian Museum, 6 College St, Sydney, \\ New South Wales 2010, Australia
}

\begin{abstract}
During the day, we used settlement-stage reef-fish larvae from light-traps to study in situ orientation, 100 to $1000 \mathrm{~m}$ from coral reefs in water 10 to $40 \mathrm{~m}$ deep, at Lizard Island, Great Barrier Reef. Seven species were observed off leeward Lizard Island, and 4 species off the windward side. All but 1 species swam faster than average ambient currents. Depending on area, time, and species, 80 to $100 \%$ of larvae swam directionally. Two species of butterflyfishes Chaetodon plebeius and Chaetodon aureofasciatus swam away from the island, indicating that they could detect the island's reefs. Swimming of 4 species of damselfishes Chromis atripectoralis, Chrysiptera rollandi, Neopomacentrus cyanomos and Pomacentrus lepidogenys ranged from highly directional to nondirectional. Only in $N$. cyanomos did swimming direction differ between windward and leeward areas. Three species (C. atripectoralis, N. cyanomos and P. lepidogenys) were observed in morning and late afternoon at the leeward area, and all swam in a more westerly direction in the late afternoon. In the afternoon, $C$. atripectoralis larvae were highly directional in sunny conditions, but nondirectional and individually more variable in cloudy conditions. All these observations imply that damselfish larvae utilized a solar compass. Caesio cuning and P. lepidogenys were non-directional overall, but their swimming direction differed with distance from the reef, implying the reef was detected by these species. Larvae of different species of reef fishes have differing orientations and apparently use different cues for orientation while in open, pelagic waters. Current direction did not influence swimming direction. Net movement by larvae of 6 of the 7 species differed from that of currents in either direction or speed, demonstrating that larval behaviour can result in non-passive dispersal, at least near the end of the pelagic phase.
\end{abstract}

KEY WORDS: Larva · Orientation · Dispersal · Connectivity · Swimming · Behaviour • Coral reef · Pomacentridae $\cdot$ Chaetodontidae $\cdot$ Lutjanidae

Resale or republication not permitted without written consent of the publisher

\section{INTRODUCTION}

A major unknown question in marine ecology is how the larval stages of benthic marine animals behave while in the pelagic environment prior to settlement (Montgomery et al. 2001, Leis \& McCormick 2002). The null assumption is that the larvae are passive, and can be treated as inert particles. Under this assumption, larval dispersal can be modelled (eg. Roberts 1997) using only current trajectory and pelagic larval duration (PLD). However, it is increasingly obvious that this null assumption is false (Sponaugle et al. 2002), particularly in taxa with more vagile and sensory-competent larvae, like fishes and decapod crustaceans (Kingsford et al. 2002, Leis et al. 2002). The dispersal questions then become: (1) to what extent larvae can control their distributions and (2) what sensory cues do larvae use for orientation to a distant settlement habitat, to remain near one, or to avoid expatriation (Montgomery et al. 2001, Leis 2002, Leis \& McCormick 2002)? Alternatively, larvae might actively disperse more than do passive particles. Recent demonstrations that self-recruitment of reef-fish populations can be much higher than expected imply that behaviour of larvae strongly influences dispersal, retention, and population connectivity (Jones et al. 1999, Swearer et al. 1999, Leis 2002). 
Orientated swimming is known in a variety of marine fishes, and in some cases, the cues used have been established with variable degrees of confidence (Montgomery et al. 2001, Kingsford et al. 2002, Myrberg \& Fuiman 2002). In the open ocean, orientated swimming by large, migratory fishes (tuna and salmon) appears to depend on magnetic and olfactory cues, and sun orientation (Ogden \& Quinn 1984). On coral reefs, migrating juvenile and adult fishes utilize compass orientation, although the cues used are unclear (Ogden \& Quinn 1984, Quinn \& Ogden 1984). Relatively little is known about larval fish behaviour, but orientated swimming has been shown in reef-fish larvae over small (Stobutzki \& Bellwood 1998) and moderate (Leis et al. 1996, Leis \& Carson-Ewart 2001) scales. Again, the cues involved are uncertain. Some fish larvae use olfactory cues over small scales to find settlement sites (Sweatman 1988, Elliott et al. 1995), and some reef-fish larvae use sound cues to navigate (Leis et al. 2002 \& unpubl., Myrberg \& Fuiman 2002). In a relevant study on crab larvae, Shanks (1995) concluded that orientated swimming depended on a sun compass and perhaps water current cues.

Laboratory studies can reveal information on orientation abilities, but few laboratory tanks are suitable for meaningful observations of the behaviour of settlement-stage reef-fish larvae that swim at speeds of 15 to $50 \mathrm{~cm} \mathrm{~s}^{-1}$ for days at a time (Leis \& Carson-Ewart 1997 , Stobutzki \& Bellwood 1997, Leis \& Stobutzki 1999), and that vertically traverse 10 to $15 \mathrm{~m}$ in a few minutes (Leis et al. 1996, Leis \& Carson-Ewart 2001). Although in situ observations of swimming and orientation behaviour of marine larval stages are difficult, they are not impossible (Bainbridge 1952, Ninos 1984, Shanks 1995, Leis et al. 1996, Leis \& Carson-Ewart 2001), and in situ research has revealed that most late-stage larvae have non-random trajectories. However, only some species have directional trajectories relative to settlement habitat (Shanks 1995, Leis et al. 1996, Leis \& Carson-Ewart 2001).

If larvae of reef fishes can orientate consistently in the pelagic environment, and are also 'effective' swimmers (i.e. swim faster than currents; Leis \& Stobutzki 1999), then they will have control over their trajectories and their settlement location. This would enable them to be very selective about what reefs they settle onto, and perhaps enable settlement to their natal reefs. The precision and accuracy of any orientation during the pelagic stage and the cues used to achieve it will influence the distance and direction of dispersal and variations in them. This would have large implications for population demographic connectivity, an issue of particular importance for coral reefs (Leis 2002).

Our goal was to determine the orientation and swimming abilities of settlement-stage larvae of several spe- cies of coral-reef fishes at various distances and bearings from reefs. We studied larvae of 7 species of 3 families (Pomacentridae, Chaetodontidae and Lutjanidae), and found species-specific behaviours in swimming speed, orientation and their variation. Some of these varied with location or time of day. These results imply the use of certain cues.

\section{MATERIALS AND METHODS}

Two study areas were used on opposite sides of Lizard Island, Queensland, northern Great Barrier Reef, Australia. One area was off the leeward (NW) side of the island off Gully Reef in Watsons Bay, and the other was off the windward (SE) side of the island just north of Coconut Beach (Fig. 1, Table 1). In each area, we made observations at 100,500 and $1000 \mathrm{~m}$ off the reef edge centred around an offshore axis perpendicular to that edge.

Species studied. Observations were made on latestage (= settlement-stage) larvae of 4 species of dam-

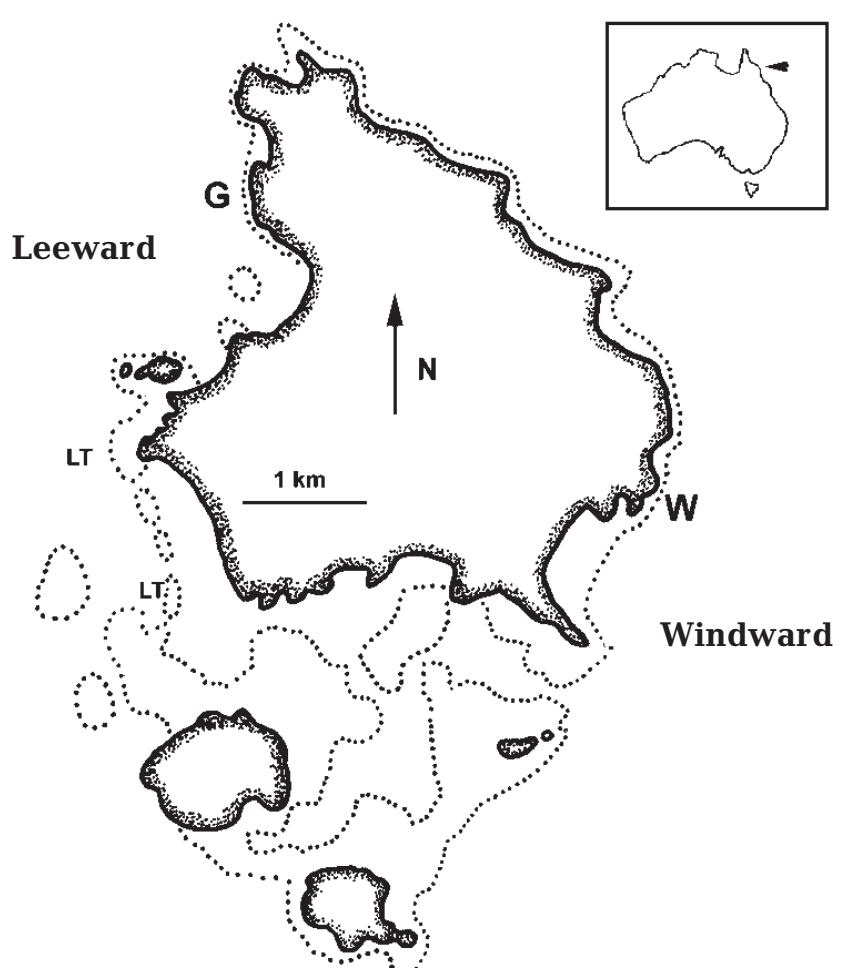

Fig. 1. Lizard Island, Great Barrier Reef $\left(14^{\circ} 40^{\prime} \mathrm{S}, 145^{\circ} 27^{\prime} \mathrm{E}\right)$. Study areas were off the NW (leeward) side, centred off the edge of Gully Reef south of Turtle Beach in Watsons Bay (G), and off the SE (windward) side, centred off the reef edge near Coconut Beach (W). At each area, 3 distances were used: 100, 500 and $1000 \mathrm{~m}$ off the reef edge (Table 1). Light-traps (LT) captured the larvae off the Research Station except during strong NW winds when they were moored off Coconut Beach 
Table 1. Characteristics of the study areas. The reefs described are the ones closest to release areas

\begin{tabular}{|lll|}
\hline Characteristic & Leeward area & Windward area \\
\hline Reef type & Fringing slope & Fringing platform \\
Depth at reef edge $(\mathrm{m})$ & $8-10$ & $15-21$ \\
Orientation of reef edge & $0-180^{\circ}$ : open & $30-210^{\circ}$ : open \\
& water to west & water to east \\
Depth 100 m off reef edge $(\mathrm{m})$ & $9-10$ & $22-25$ \\
Depth 500 m off reef edge $(\mathrm{m})$ & $14-19$ & $32-33$ \\
Depth 1000 m off reef edge $(\mathrm{m})$ & $18-21$ & $33-36$ \\
Bottom type & Sand, scattered & Sand, with dense \\
& sparse algae & Halimeda mead- \\
& & ows offshore \\
\hline
\end{tabular}

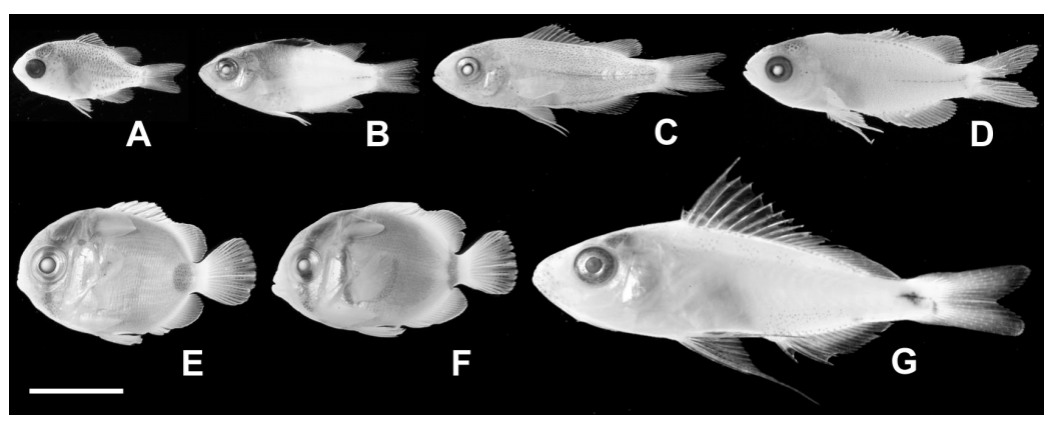

Fig. 2. Preserved settlement-stage larvae (scale bar $=5 \mathrm{~mm}$ ) of the 7 study species. In life, all larvae had silvery eyes and gut areas, but were otherwise transparent with only the limited melanistic areas shown, except as noted: (A) Chromis atripectoralis, silvery laterally, blue-green dorsally; (B) Chrysiptera rollandi, blue anterio-dorsally; (C) Neopomacentrus cyanomos, silvery laterally, grey dorsally, yellowish tail; (D) Pomacentrus lepidogenys, yellowish tail; (E) Chaetodon plebeius, yellow overall; (F) C. aureofasciatus, yellow overall; (G) Caesio cuning, yellowish tail selfish (Pomacentridae): Chromis atripectoralis, Chrysiptera rollandi, Neopomacentrus cyanomos, and Pomacentrus lepidogenys; 2 species of butterflyfish (Chaetodontidae): Chaetodon aureofasciatus and C. plebeius; and 1 species of fusilier (Lutjanidae, Caesioninae): Caesio cuning (Fig. 2). For brevity, we refer to all individuals observed as larvae, but acknowledge that some nomenclatures may use different terms for either some or all of these species late in their pelagic phase. These species were used because sufficient numbers were present in our light-trap catches for adequate replication, and they were amenable for in situ observations (Leis et al. 1996, Leis \& Carson-Ewart 1998). They encompass a variety of sizes, spawning modes, PLDs, settlement requirements and trophic categories (Table 2, Fig. 2).

Field procedures. Larvae used were captured by light-traps located off the Lizard Island reefs. They were released individually on the day of capture by divers and their behaviour observed following the procedures of Leis et al. (1996) and Leis \& CarsonEwart (1997). Briefly, 2 divers released a larva from a small container, and once the larva chose its initial trajectory, the divers followed behind.

Table 2. Characteristics of the species studied. Sizes are of settlement-stage larvae from light-traps. Egg type from Leis \& CarsonEwart (2000). Pelagic duration, from Leis (1989), Thresher et al. (1989), Wellington \& Victor (1989). Settlement requirements from Leis \& Carson-Ewart (2002, unpubl.). Trophic category from Allen (1991), Carpenter (1987), Allen et al. (1998)

\begin{tabular}{|c|c|c|c|c|c|}
\hline Species & $\begin{array}{c}\text { Size } \\
(\mathrm{mm} \text { SL) }\end{array}$ & Egg type & $\begin{array}{c}\text { Pelagic } \\
\text { duration (d) }\end{array}$ & $\begin{array}{l}\text { Settlement } \\
\text { requirements }\end{array}$ & $\begin{array}{l}\text { Post-settlement } \\
\text { trophic category }\end{array}$ \\
\hline $\begin{array}{l}\text { Chromis atripectoralis } \\
\text { Welander \& Schultz }\end{array}$ & $6-8$ & Demersal & $16-21$ & $\begin{array}{l}\text { Schools of similar-sized } \\
\text { recruits on live coral }\end{array}$ & Zooplanktivore \\
\hline $\begin{array}{l}\text { Chrysiptera rollandi } \\
\text { (Whitley) }\end{array}$ & $9-10$ & Demersal & $16-20$ & Dead coral & Omnivore \\
\hline $\begin{array}{l}\text { Neopomacentrus cyanomos } \\
\text { (Bleeker) }\end{array}$ & $11-13$ & Demersal & $17-19$ & Unknown & Zooplanktivore \\
\hline $\begin{array}{l}\text { Pomacentrus lepidogenys } \\
\text { Fowler \& Ball }\end{array}$ & $11-13$ & Demersal & 20 & Live coral, algae & Omnivore \\
\hline $\begin{array}{l}\text { Chaetodon aureofasciatus } \\
\text { Macleay }\end{array}$ & $10-11$ & Pelagic & $20-43^{a}$ & Live coral & Coralivore/herbivore \\
\hline $\begin{array}{l}\text { Chaetodon plebeius } \\
\text { Cuvier }\end{array}$ & $10-11$ & Pelagic & $21-56$ & Unknown & Coralivore \\
\hline $\begin{array}{l}\text { Caesio cuning } \\
\text { (Bloch) }\end{array}$ & $19-21$ & Pelagic & $?$ & $\begin{array}{l}\text { Schools of similar-sized } \\
\text { recruits on lagoon reefs }\end{array}$ & Zooplanktivore \\
\hline
\end{tabular}


The direction the diver was facing when (s)he released the larva was randomized. All larvae were released at a depth of $5 \mathrm{~m}$, except the highly surface orientated species, Neopomacentrus cyanomos, which was released at $3 \mathrm{~m}$ to avoid very rapid ascents. Each larva was used for only 1 trial, and aside from a few recaptured individuals for voucher purposes, was allowed to swim free at the end. Details and justification of the procedure are in Leis et al. (1996) and Leis \& CarsonEwart $(1997,1998)$.

We made observations both in the morning and afternoon. Any morning-afternoon differences in behaviour might have been partially due to the effects of holding larvae for a few hours in a covered container prior to afternoon release. Larvae observed in the afternoon were held in the same container we used to hold larvae prior to morning release, and apart from some differences in swimming direction (see 'Results'), there were no obvious behavioural differences between morning and afternoon released larvae. Holding larvae for a few hours prior to afternoon releases is unavoidable if light traps are the source of the larvae.

We measured swimming speed, depth, and orientation. We attempted to observe each larva for $10 \mathrm{~min}$, taking measurements of swimming direction and depth every 30 s. Speed was calculated from distance travelled as measured by a flowmeter over the full period of observation (Leis \& Carson-Ewart 1997). Larvae were not followed deeper than $18 \mathrm{~m}$ for safety reasons, so observations on some individuals were curtailed. At other times, we lost sight of the larvae or they were eaten by predators. Overall, $86 \%$ of the observations had a duration of $10 \mathrm{~min}$, and most of the remainder had a duration of at least 5 min.

Our goal was to obtain observations on at least 10 individuals of each species at each distance offshore at each area, although this was not always accomplished (Table 3). At the leeward area, all 7 species were observed in the morning and 3 species in the afternoon. In addition, we observed 1 species in the afternoon under
2 meteorological conditions $(100 \%$ cloud, and clear skies). On the windward side, we observed 4 species.

Observations were taken primarily over 3 summers (November to February of 1998/99, 1999/2000 and 2000/ 2001), but a few observations taken in the summers of 1995/96 and 1997/98 were also included (Table 3). Our ability to make behavioural observations depended on the unpredictable availability of species in the light traps, and to a lesser extent on weather conditions. The latter resulted in fewer observations off the windward side of the island. In most cases, observations on a particular species at any location or time were taken over a number of days, and usually, a number of summers (Table 3).

In most cases, observations were taken without regard to meteorological conditions, especially cloud. The afternoon observations were made under nearly entirely clear skies, except observations on 2 days in February 1999 when 100\% cloud cover prevailed. These sunny and cloudy afternoon observations were treated separately.

During 1998 to 2001 we measured currents with a drogue at $5 \mathrm{~m}$ depth. A Global Positioning System (GPS) reading was taken at the start and end of each drogue run, and used to determine current speed and direction, usually for a period of about $1 \mathrm{~h}$. A GPS reading was also taken at the start and end of each larva observation run, as the divers left and returned to the surface. This provided an estimate of the net speed and net direction for the fish (i.e. it included both the current and the swimming component, and represents movement relative to the bottom, whereas the direct observations of the fish gave movement relative to the water column). However, the precision and accuracy of these net estimates is decreased because they included the time and current drift that took place while the divers descended to $5 \mathrm{~m}$ to begin and then resurfaced once observations were complete. Further, the accuracy of the GPS readings varied temporally due to policies of the GPS satellite operator.

Data presentation and analysis. This paper concentrates on swimming speeds and directions, and includes

Table 3. Number of individual larvae observed at each area and time, for leeward (lee) and windward areas. $\mathrm{n}$ is number of individuals observed at each of 100, 500 and $1000 \mathrm{~m}$ offshore. For Chromis atripectoralis, Lee pm, numbers in parentheses are of individuals observed under conditions of $100 \%$ cloud. Number of individuals observed on any day varied widely

\begin{tabular}{|lllll|}
\hline Species & $\begin{array}{c}\text { Lee am } \\
\mathrm{n}\end{array}$ & \multicolumn{1}{c}{$\begin{array}{c}\text { Lee } \mathrm{pm} \\
\mathrm{n}\end{array}$} & $\begin{array}{c}\text { Windward am } \\
\mathrm{n}\end{array}$ & $\begin{array}{l}\text { Number of days: } \\
\text { summers of observation }\end{array}$ \\
\hline $\begin{array}{l}\text { Chromis atripectoralis } \\
\text { Chrysiptera rollandi }\end{array}$ & $16,16,16$ & $9(4), 10(6), 10(5)$ & $11,16,12$ & $30: 98 / 99,99 / 00$ \\
Neopomacentrus cyanomos & $11,17,12$ & $0,0,0$ & $13,12,11$ & $15: 95 / 96,99 / 00,00 / 01$ \\
Pomacentrus lepidogenys & $15,18,10$ & $10,11,10$ & $12,16,15$ & $32: 95 / 96,98 / 99,99 / 00,00 / 01$ \\
Chaetodon aureofasciatus & $13,16,12$ & $8,7,7$ & $0,0,0$ & $15: 96 / 97,99 / 00,00 / 01$ \\
Chaetodon plebeius & $10,10,13$ & $0,0,0$ & $14,13,17$ & $24: 95 / 96,98 / 99,99 / 00$ \\
Caesio cuning & $10,13,11$ & $0,0,0$ & $0,0,0$ & $17: 95 / 96,98 / 99,99 / 00,00 / 01$ \\
& $3,4,4$ & $0,0,0$ & $0,0,0$ & $3: 95 / 96,00 / 01$ \\
\hline
\end{tabular}


no data published in Leis et al. (1996). Information on swimming depth will be presented elsewhere. All bearings are given as degrees magnetic, which in the study area differs from degrees true by $7^{\circ}$. Cardinal directions are not abbreviated, but other directions are abbreviated (e.g. SE for southeast). Standard Error is abbreviated to 'se' to avoid confusion with SE for southeast. Mean bearing is abbreviated MB. From these bearings and the flowmeter data we estimated swimming direction and speed relative to the water. We refer to 2 types of locations in our analyses: areas (or, sides of Lizard Island) and distance (from the reef edge).

Circular statistical procedures followed Batschelet (1981) and Zar (1996). Mean vector length (r), is a measure of angular dispersion ranging from 0 (maximum dispersion) to 1 (no dispersion). Statistical comparisons of $\mathrm{r}$ were after arc-sine transformation. The Rayleigh test was used for single-sample hypotheses on directional swimming. Watson's F-test was used for hypotheses on directional swimming involving more than 1 sample. Most of the circular statistical procedures were performed with Oriana software (Kovach Computing Services), and Figs. 3 to 10 were produced with Oriana. Second-order directional statistical tests (i.e. means of means), require that the number of observations per individual be equal (Batschelet 1981). Our data did not meet this requirement, although they approached it. An alternative is to use only the mean angles for each individual, but this ignores the variation associated with that mean (Batschelet 1981). We used the mean angles and the 1-sample Rayleigh test, but in order to take some account of variation within individual trajectories, we excluded individual trajectories that prior Rayleigh testing had shown were not directional (these constituted about $8 \%$ of all trajectories). We have found that both the

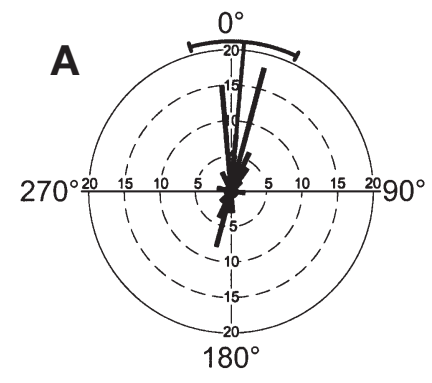

Leeward

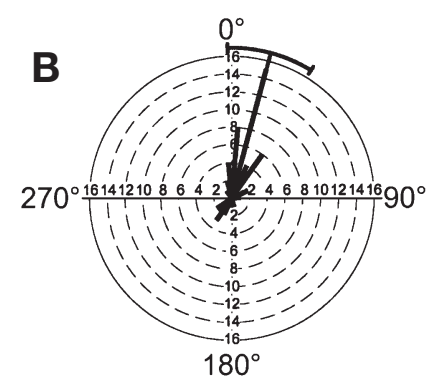

Windward
Fig. 3. Frequency distribution of current direction in the study areas during the observations of larval behaviour. Drogue runs were done during most larval observations. All 3 distances at each area are pooled, resulting in 91 observations in the leeward area (A) and 54 observations in the windward area (B). Bearings are grouped into $10^{\circ}$ intervals, the mean bearing is the radius that pierces the outer circle, and the outer heavy arc delimits the $95 \%$ CI of the mean second-order Moore test and the modified Rayleigh procedure give the same results. We report here only the Rayleigh test results. The nature of our observations (several species, locations and times), meant that multiple testing, with its attendant risks, took place (e.g. 14 tests of directionality were performed, 1 for each species in each area and time). Rather than make adjustments to the significance levels (this is, in itself, controversial), we report actual $\mathrm{p}$-values, but consider $\mathrm{p}<0.05$ to constitute a 'significant' result.

Current directions were strongly bimodal (see 'Results'). The influence of current direction on swimming direction was examined by grouping swimming trajectories according to the prevailing current direction (north or south).

\section{RESULTS}

\section{Currents and swimming speed}

In both areas currents were overwhelmingly more frequent and faster to the north (consistent with studies of currents in the area; Frith et al. 1986, Leis 1986). Mean current speeds were slightly faster at the windward area and at more offshore distances. In both areas, the flow was strongly bimodal, along a NNE-SSW axis (Fig. 3), but with a large majority of velocities to the NNE (ca. 4:1 and 2:1 at windward and leeward areas, respectively). Overall mean current speeds ( \pm se) were: windward 15.0 $( \pm 1.6) \mathrm{cm} \mathrm{s}^{-1}$ and leeward $12.2( \pm 0.9) \mathrm{cm} \mathrm{s}^{-1}$. The fastest speeds measured were 40.7 and $31.3 \mathrm{~cm} \mathrm{~s}^{-1}$ in windward and leeward areas, respectively. In the windward area, mean current speeds were $12.5,16.6$ and $16.0 \mathrm{~cm} \mathrm{~s}^{-1}$ at 100,500 and $1000 \mathrm{~m}$, respectively. At the leeward area, the corresponding values were 11.1, 10.4 and $15.1 \mathrm{~cm}$ $\mathrm{s}^{-1}$. Currents were faster to the north than the south at both areas. In the windward area, speeds were 16.6 $( \pm 1.7)$ and $8.2( \pm 0.9) \mathrm{cm} \mathrm{s}^{-1}$ to the north and south, respectively, whereas at the leeward area, the same values were $13.7( \pm 1.0)$ and $8.4( \pm 1.3) \mathrm{cm} \mathrm{s}^{-1}$.

Mean swimming speeds of the 7 species ranged from 11.6 to $33.9 \mathrm{~cm} \mathrm{~s}^{-1}$ (Table 4 ) \pm se of 0.9 to 1.9 . In only 1 case did the mean swimming speed for a species differ significantly among areas or time of day. Neopomacentrus cyanomos had a mean speed of $23.7( \pm 1.15) \mathrm{cm}$ $\mathrm{s}^{-1}$ at the lee area in the morning, $21.1( \pm 1.17) \mathrm{cm} \mathrm{s}^{-1}$ in the windward area, and $26.8( \pm 1.33) \mathrm{cm} \mathrm{s}^{-1}$ at the lee area in the afternoon (1-way ANOVA, $\mathrm{p}=0.008)$.

\section{Variability in swimming direction}

The vast majority of individuals had directional trajectories ( $p<0.05$, Rayleigh test). Depending on 
Table 4. Swimming speed $\left(\mathrm{cm} \mathrm{s}^{-1}\right)$ of larvae. $\mathrm{n}$ : number of mean speed estimates. se: standard error. See Table 3 for number of individuals observed at each area and time

\begin{tabular}{|lccc|}
\hline Species & $\mathrm{n}$ & Range of means & Range of se \\
\hline Chromis atripectoralis & 4 & $21.6-25.2$ & $0.9-1.6$ \\
Chrysiptera rollandi & 2 & $11.6-12.1$ & $0.81-0.82$ \\
Neopomacentrus cyanomos & 3 & $21.1-26.8$ & $1.2-1.3$ \\
Pomacentrus lepidogenys & 2 & $15.1-16.8$ & $1.2-1.8$ \\
Chaetodon aureofasciatus & 2 & $18.4-19.6$ & $1.5-1.6$ \\
Chaetodon plebeius & 1 & 25.1 & 1.9 \\
Caesio cuning & 1 & 33.9 & 1.7 \\
\hline
\end{tabular}

species, the percentage of individuals with directional trajectories ranged from 80 to $100 \%$, and averaged $94.3,87.5$ and $90.3 \%$ at leeward am, windward am and leeward pm areas, respectively. Within species, differences between areas or times in the percentage of directional individuals were small $(<10 \%)$, with 3 exceptions. These were Chromis atripectoralis with differences among times of up to $20 \%$, Neopomacentrus cyanomos with differences of $15 \%$, and Chaetodon aureofasciatus with a difference of $12.7 \%$. These differences are best examined by the comparison of r-values, below.

In only a few cases did directional variability vary among distances within an area. The r-values for individuals were compared among distances, areas, or times by ANOVA, and in most cases, no differences were found among distances within an area. There were 3 exceptions: Chaetodon aureofasciatus in the windward area $(100<500<1000, p=0.05)$, C. plebeius in the leeward area in the morning $(100<500<1000$, $\mathrm{p}=0.04)$, and Neopomacentrus cyanomos in the leeward area in the morning $(100<1000<500, p=0.01)$. In each of these cases, the distance closest to shore had the greatest variability in direction (i.e. lowest mean r-value), with $r$ being 0.61 to 0.74 at $100 \mathrm{~m}$, and 0.75 to 0.90 offshore.

Four comparisons of directional variability between windward and leeward areas were possible, and only 1 significant difference was found. In Chromis atripectoralis, the leeward trajectories were more variable than the windward ones $(p=0.003$, ANOVA), whereas no windward-leeward differences were found for Chaetodon aureofasciatus, Chrysiptera rollandi or Neopomacentrus cyanomos (all $\mathrm{p}>0.40$ ).

Differences in directional variability between morning and afternoon at the leeward area were found in some of the 4 possible comparisons by ANOVA. Clear differences were found only for
Chromis atripectoralis. This species had significantly more variable $(p=0.0006)$ trajectories on cloudy afternoons $(r=0.64)$ than on sunny afternoons $(r=0.86)$. In the leeward area, swimming direction was significantly more variable $(p=0.009)$ on mornings $(r=0.74)$ than on sunny afternoons $(r=0.86)$, but we found no significant difference between mornings and cloudy afternoons $(\mathrm{p}>0.10)$. In Pomacentrus lepidogenys, directional variability was marginally higher $(\mathrm{p}=0.055)$ in the morning $(r=0.72)$ than in the afternoon $(r=0.82)$. In contrast, no difference between morning and afternoon directional variability was found for Neopomacentrus cyanomos ( $p>0.10)$.

\section{Swimming direction}

At the windward area for the 4 species observed, no differences in swimming direction among distances $(100,500$ and $1000 \mathrm{~m}$ offshore) were found by Watson's F-test. At the leeward area, significant differences among distances were found in 8 of 10 tests (Table 5), but few of these clearly constituted differences in swimming direction among offshore distances. Relatively few of the swimming directions at individual offshore distances were significantly directional (i.e. $p<0.05$, Rayleigh test), probably because of the low number of observations, and ambiguous statistical results (e.g. $\mathrm{A}>\mathrm{C}$, but $\mathrm{A}=\mathrm{B}$ and $\mathrm{B}=\mathrm{C}$ ) were common. In only 4 cases was at least 1 distance significantly directional, and the results unambiguous. For Chromis atripectoralis, swimming directions at the 3 distances, although significantly different, were all to the SE, i.e. onshore. Similarly, for Chaetodon plebeius, mean swimming directions at all 3 distances were offshore. For Pomacentrus lepidogenys, both in the morning and

Table 5. Comparisons of mean swimming direction among distances within the leeward (Lee) area. No differences were found at the windward area. The values are mean bearing in degrees. Bearings with the same font style, or underlined, do not differ significantly ( $\mathrm{p}>0.05$, Watson's $F$-test). ns indicates that none of the distance-specific bearings differed in that area; - : no data; ${ }^{*}$ : swimming was significantly directional ( $\mathrm{p}<0.05$, Rayleigh test)

\begin{tabular}{|c|c|c|c|c|c|c|}
\hline \multirow[t]{2}{*}{ Species } & \multicolumn{3}{|c|}{ Lee am, distance (m) } & \multicolumn{3}{|c|}{ Lee $\mathrm{pm}$, distance $(\mathrm{m})$} \\
\hline & 100 & 500 & 1000 & 100 & 500 & 1000 \\
\hline Chromis atripectoralis & $151^{*}$ & $\underline{105}^{*}$ & $166^{*}$ & & ns & \\
\hline Chrysiptera rollandi & 165 & $\underline{346}$ & 227 & & - & \\
\hline Neopomacentrus cyanomos & & $\mathrm{ns}$ & & $\underline{254}$ & $\underline{325}$ & 187 \\
\hline Pomacentrus lepidogenys & $\underline{200}$ & $\underline{266}$ & $93^{*}$ & $\underline{188}$ & $\underline{249}$ & $163^{*}$ \\
\hline Chaetodon aureofasciatus & 275 & $\underline{267}$ & $\underline{10}$ & & - & \\
\hline Chaetodon plebeius & $\underline{215}$ & 291 & $308^{*}$ & & - & \\
\hline Caesio cuning & $273^{*}$ & $\underline{46}^{*}$ & 310 & & - & \\
\hline
\end{tabular}




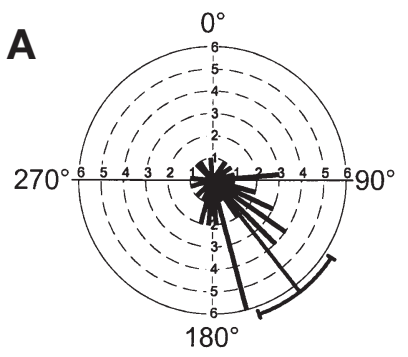

Leeward am

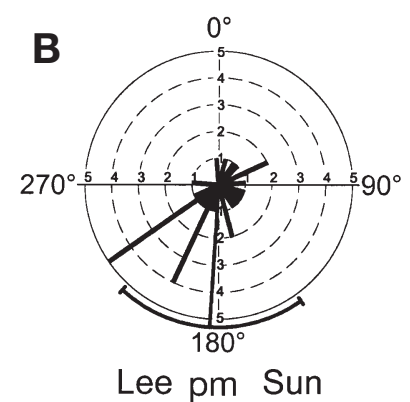

Lee pm Sun
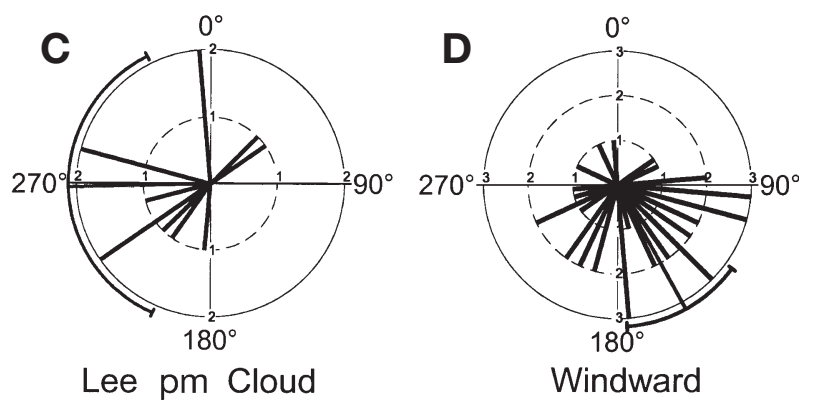

Fig. 4. Chromis atripectoralis. Frequency distribution of mean swimming directions of larvae with directional trajectories. Mean bearings of individual fish are grouped into $10^{\circ}$ intervals. The overall mean bearing $(\mathrm{MB})$ is the radius that pierces the outer circle, and the outer heavy arc delimits the $95 \% \mathrm{CI}$ of the mean. $\mathrm{r}$ is the mean vector length, $\mathrm{p}$ is from the Rayleigh test. (A) Leeward area, morning, $\mathrm{n}=42, \mathrm{r}=0.58, \mathrm{MB}=142^{\circ}, \mathrm{p}<0.0001$; (B) leeward area, afternoon, sunny conditions, $\mathrm{n}=29, \mathrm{r}=0.36, \mathrm{MB}=198^{\circ}$, $\mathrm{p}=0.02$; (C) leeward area, afternoon, cloudy conditions, $\mathrm{n}=12, \mathrm{r}=0.39, \mathrm{MB}=269^{\circ}, \mathrm{p}>0.10 ;(\mathrm{D})$ windward area, morning, $\mathrm{n}=39$, $\mathrm{r}=0.48, \mathrm{MB}=151^{\circ}, \mathrm{p}<0.0001$

afternoon, mean swimming direction at $1000 \mathrm{~m}$ was onshore, whereas at the other distances it was to the SSW to SW (offshore). Caesio cuning swam offshore at 100 and $1000 \mathrm{~m}$, but onshore at $500 \mathrm{~m}$. The low number of observations of the latter species make this result somewhat suspect, but it is notable that such differences were found at all locations less than $1000 \mathrm{~m}$ apart.

Four of the 7 species had significant directional swimming patterns (Rayleigh test) when overall patterns (i.e. pooled among distances within areas) were considered (Figs. 4 to 10). Chromis atripectoralis (Fig. 4) swam directionally SE at both leeward and windward areas in the morning: i.e. onshore in the lee area, but offshore in the windward area. In the afternoon in the lee area, this species swam SSW, on average, during sunny periods, but had no overall directionality during cloudy periods (mean direction was westerly, but was not significant). When all afternoon trajectories for $C$. atripectoralis were pooled, they were significantly directional SSW $\left(\mathrm{MB}=206^{\circ}, \mathrm{p}=0.03\right)$.

The 2 Chaetodon species had similar patterns of directional swimming. Neither the leeward nor the windward distributions of Chrysiptera aureofasciatus
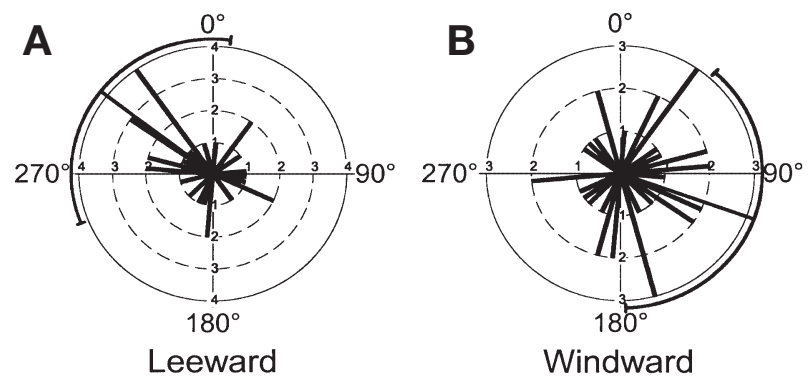

Fig. 5. Chaetodon aureofasciatus. Frequency distribution of mean swimming directions of larvae with directional trajectories. Symbols as in Fig. 4. (A) Leeward area, morning, $\mathrm{n}=30$, $\mathrm{r}=0.24, \mathrm{MB}=308^{\circ}, \mathrm{p}>0.10 ;(\mathrm{B})$ windward area, morning, $\mathrm{n}=37, \mathrm{r}=0.19, \mathrm{MB}=110^{\circ}, \mathrm{p}>0.10$
(Fig. 5) were significantly directional, but mean direction was WNW in the leeward area and ESE in the windward area: i.e. offshore at both. For C. plebeius (Fig. 6), the leeward distribution was significantly directional to the west: i.e. offshore.

Neither Chrysiptera rollandi nor Caesio cuning had significant directional overall swimming distributions. C. rollandi (Fig. 7) swam, on average, S to SW at both

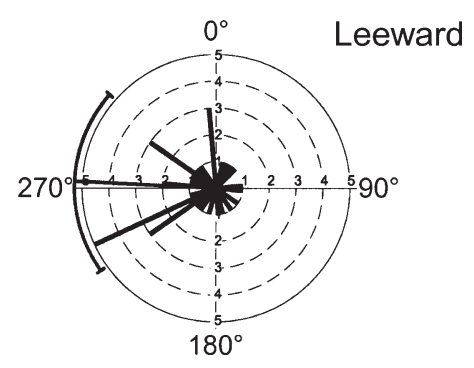

Fig. 6. Chaetodon plebeius. Frequency distribution of mean swimming directions of larvae with directional trajectories. Leeward area, morning, $\mathrm{n}=34, \mathrm{r}=0.34, \mathrm{MB}=272^{\circ}, \mathrm{p}=0.02$. Symbols as in Fig. 4
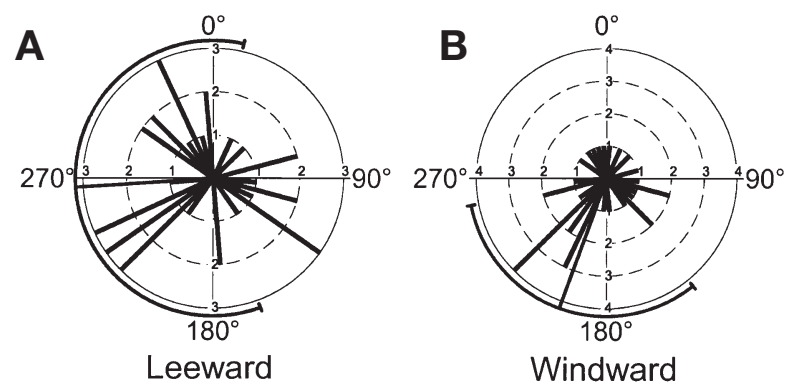

Fig. 7. Chrysiptera rollandi. Frequency distribution of mean swimming directions of larvae with directional trajectories. Symbols as in Fig. 4. (A) Leeward area, morning, $\mathrm{n}=36, \mathrm{r}=0.12$, $\mathrm{MB}=242^{\circ}, \mathrm{p}>0.10$; (B) windward area, morning, $\mathrm{n}=32$, $\mathrm{r}=0.24, \mathrm{MB}=181^{\circ}, \mathrm{p}>0.10$ 




Fig. 8. Caesio cuning. Frequency distribution of mean swimming directions of larvae with directional trajectories. Leeward area, morning, $\mathrm{n}=11, \mathrm{r}=0.43, \mathrm{MB}=332^{\circ}, \mathrm{p}>0.10$. Symbols as in Fig. 4

leeward and windward areas (more-or-less parallel to shore), but neither distribution was significantly directional. Caesio cuning (Fig. 8) swam on average NNW (offshore), but this overall distribution was not significantly directional, undoubtedly due to among-distance differences in swimming direction.

In the leeward area Pomacentrus lepidogenys (Fig. 9) on average swam SE (onshore) in the morning and SSW (roughly parallel to shore) in the afternoon. However, only the afternoon distribution was significantly directional, and, as with Caesio cuning, this was undoubtedly due to among-distance differences in swimming direction.

Neopomacentrus cyanomos (Fig. 10) swam directionally on the windward side, but not on the leeward side. On the leeward side, this species swam on average ENE in the morning, and west in the afternoon, although neither distribution was significantly directional. On the windward side, this species swam to the south, and this distribution was significantly directional.

Windward-leeward comparisons of swimming directions were possible by Watson's F-test for 4 species, and 2 were significantly different. The distribution of swimming directions in Chaetodon aureofasciatus was significantly different $(p=0.0003)$ in the 2 areas, and in both cases mean direction was offshore (Fig. 5). Neopomacentrus cyanomos larvae also differed significantly in swimming direction $(\mathrm{p}=0.002)$ in the 2 areas (Fig. 10), swimming ENE (onshore) in the leeward area, and south (roughly parallel to shore) in the windward area. In contrast, Chromis atripectoralis swam SE in both areas in the morning, and the 2 mean directions were not different ( $p>0.10$, Fig. 4). Chrysiptera rollandi did not differ in swimming direction between areas $(p>0.10)$,
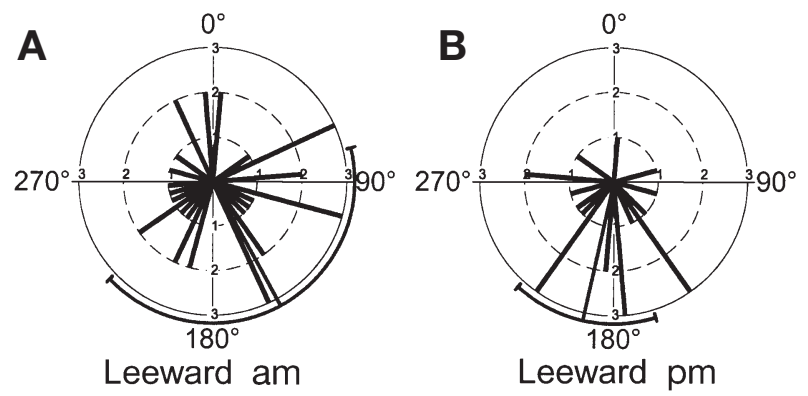

Fig. 9. Pomacentrus lepidogenys. Frequency distribution of mean swimming directions of larvae with directional trajectories. Symbols as in Fig. 4. (A) Leeward area, morning, $\mathrm{n}=37$, $\mathrm{r}=0.17, \mathrm{MB}=151^{\circ}, \mathrm{p}>0.10 ;(\mathrm{B})$ leeward area, afternoon, $\mathrm{n}=20, \mathrm{r}=0.53, \mathrm{MB}=195^{\circ}, \mathrm{p}=0.003$

and it had no swimming directionality in either area (Fig. 7).

In the afternoon, swimming directions were more westerly than in the morning. Two of the 3 species (all pomacentrids) for which we made morning-afternoon comparisons (only at the leeward area) of mean swimming direction differed significantly (Watson's F-test) between times. In the morning, Chromis atripectoralis swam SE, but in the afternoon, its mean swimming direction was significantly more westerly, regardless of whether comparisons were made with sunny periods ( $p=0.03)$, cloudy periods $(p=0.00004)$ or with both combined ( $p=0.001$, Fig. 4 ). In the afternoon, swimming directions of this species were significantly more westerly under cloudy conditions than under sunny conditions $(p=0.03)$. Similarly, Neopomacentrus cyanomos larvae swam SE in the morning and SSW in the afternoon, and the 2 means were significantly different $(p=0.002$, Fig. 10). Although in the afternoon mean swimming direction of Pomacentrus lepidogenys larvae was more westerly than in the morning (SSW vs $\mathrm{SE}$ ), the 2 means were not significantly different ( $p>0.10$, Fig. 9).



Leeward am



Leeward pm

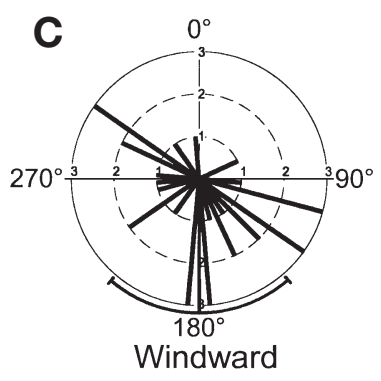

Fig. 10. Neopomacentrus cyanomos. Frequency distribution of mean swimming directions of larvae with directional trajectories. Symbols as in Fig. 4. (A) Leeward area, morning, $\mathrm{n}=41, \mathrm{r}=0.25, \mathrm{MB}=78^{\circ}, \mathrm{p}=0.07$; (B) leeward area, afternoon, $\mathrm{n}=28$, $\mathrm{r}=0.15, \mathrm{MB}=272^{\circ}, \mathrm{p}>0.10 ;(\mathrm{C})$ windward area, morning, $\mathrm{n}=33, \mathrm{r}=0.33, \mathrm{MB}=180^{\circ}$, $\mathrm{p}=0.03$ 


\section{Influence of current direction on swimming direction}

It was possible to make 12 (species $\times$ area $\times$ time) comparisons of swimming direction under different current directions (in other cases, too few observations of behaviour under southerly currents were available for valid testing). In 11 cases, there was no indication of any influence of current direction on swimming direction. The difference in mean swimming bearing between south and north currents in these 11 cases ranged from 12 to $81^{\circ}$ (mean $32^{\circ}$, SE $7^{\circ}$ ), and in no cases were the mean swimming bearings significantly different (Watson's F-test, $\mathrm{p}>0.05$ ). The 12th case was Chaetodon plebeius (lee, am) wherein the mean swimming bearings were significantly different $(p=0.03)$ : in southerly currents, the mean swimming bearing was NE $\left(34^{\circ}\right)$, whereas in northerly currents, it was west $\left(256^{\circ}\right)$. However, only 5 individuals of this species were observed in southerly currents (22 in northerly currents), so the reliability of the result for this species is somewhat dubious. Thus, we conclude there was little evidence that current direction influenced swimming direction.

\section{Net swimming direction and speed}

Net swimming directions measured by the locations of the divers at the start and end of the observations on each larva represent the combination of current and larval fish velocity. Of most interest regarding orienta- tion are net swimming directions or speeds that differ from those of current directions. This was examined either in terms of the actual compass directions, or whether net swimming direction was more toward or away from the reef than the current, or whether the component of net fish speed along the current axis differed from current speed.

Net swimming directions of both Chaetodon plebeius and Chromis atripectoralis differed in every case from current compass direction (Table 6). No other species had such differences. The differences for C. plebeius and $C$. atripectoralis are expected based on their swimming directions and the current regime. Both species had a strong east-west component to their swimming, and highly directional swimming, and this would produce the greatest deviation in net swimming from the north-south current. Other species either did not have highly directional swimming or lacked a strong eastwest swimming component.

In no case did net swimming direction of any species differ between windward and leeward areas. In contrast, all 3 of the testable species (Chromis atripectoralis, Neopomacentrus cyanomos and Pomacentrus lepidogenys) differed in net swimming direction between morning and afternoon (tested at the leeward area only, $\mathrm{p}<0.02$, Watson's F-test). In each case, net swimming direction in the afternoon was westerly, whereas in the morning it was easterly (Table 6).

The net swimming direction of individual larvae might be either more toward the reef or more away from it than was the current direction, or it might not differ. We found cases of each, and again, it was the

Table 6. Mean net swimming direction and its difference from mean current direction in degrees, for leeward (lee) and windward areas. Parentheses contain $\mathrm{p}$ from Rayleigh test (mean direction) and Watson's F-test (difference from current). For Rayleigh test, $\mathrm{p}<0.05$ indicates directional net swimming. For Watson's $F$-test, $\mathrm{p}<0.05$ indicates net swimming direction significantly different from current direction, ns indicates $\mathrm{p}>0.10$. Square brackets contains the direction in which net swimming differs from current. -: no data

\begin{tabular}{|c|c|c|c|c|c|c|}
\hline \multirow{2}{*}{ Species } & \multicolumn{2}{|c|}{ Lee am } & \multicolumn{2}{|c|}{$\longrightarrow$ Lee $\mathrm{pm}$} & \multicolumn{2}{|c|}{ Windward } \\
\hline & $\begin{array}{l}\text { Mean } \\
\text { direction } \\
\text { (p) }\end{array}$ & $\begin{array}{l}\text { Difference } \\
\text { from current } \\
\text { (p) }\end{array}$ & $\begin{array}{l}\text { Mean } \\
\text { direction } \\
\text { (p) }\end{array}$ & $\begin{array}{l}\text { Difference } \\
\text { from current } \\
\text { (p) }\end{array}$ & $\begin{array}{l}\text { Mean } \\
\text { direction } \\
\text { (p) }\end{array}$ & $\begin{array}{c}\text { Difference } \\
\text { from current } \\
\text { (p) }\end{array}$ \\
\hline Chromis atripectoralis & $\begin{array}{c}107 \\
(0.003)\end{array}$ & $\begin{array}{c}151[E] \\
(0.00001)\end{array}$ & $\begin{array}{l}254 \\
\text { (ns) }\end{array}$ & $\begin{array}{l}141[\mathrm{~W}] \\
(0.0003)\end{array}$ & $\begin{array}{c}99 \\
(0.05)\end{array}$ & $\begin{array}{c}102[E] \\
(0.0002)\end{array}$ \\
\hline Chrysiptera rollandi & $\begin{array}{c}332 \\
(0.01)\end{array}$ & $\begin{array}{c}36[\mathrm{~W}] \\
(\mathrm{ns})\end{array}$ & - & - & $\begin{array}{l}17 \\
\text { (ns) }\end{array}$ & $\begin{array}{l}8[\mathrm{E}] \\
(\mathrm{ns})\end{array}$ \\
\hline Neopomacentrus cyanomos & $\begin{array}{c}22 \\
(0.00002)\end{array}$ & $\begin{array}{c}15[\mathrm{E}] \\
(\mathrm{ns})\end{array}$ & $\begin{array}{l}264 \\
\text { (ns) }\end{array}$ & $\begin{array}{c}56[\mathrm{~W}] \\
\text { (ns) }\end{array}$ & $\begin{array}{c}47 \\
(0.01)\end{array}$ & $\begin{array}{c}31[\mathrm{E}] \\
(\mathrm{ns})\end{array}$ \\
\hline Pomacentrus lepidogenys & $\begin{array}{l}27 \\
\text { (ns) }\end{array}$ & $\begin{array}{c}35[\mathrm{E}] \\
(\mathrm{ns})\end{array}$ & $\begin{array}{c}270 \\
(0.08)\end{array}$ & $\begin{array}{c}13[\mathrm{~W}] \\
\text { (ns) }\end{array}$ & - & - \\
\hline Chaetodon aureofasciatus & $\begin{array}{c}3 \\
(0.03)\end{array}$ & $\begin{array}{c}22[\mathrm{~W}] \\
\text { (ns) }\end{array}$ & - & - & $\begin{array}{c}32 \\
(<0.000001)\end{array}$ & $\begin{array}{l}9[\mathrm{E}] \\
(\mathrm{ns})\end{array}$ \\
\hline Chaetodon plebeius & $\begin{array}{l}302 \\
\text { (ns) }\end{array}$ & $\begin{array}{l}75[\mathrm{~W}] \\
(0.02)\end{array}$ & - & - & - & - \\
\hline Caesio cuning & $\begin{array}{c}4 \\
(0.000001)\end{array}$ & $\begin{array}{c}6[\mathrm{~W}] \\
\text { (ns) }\end{array}$ & - & - & - & - \\
\hline
\end{tabular}


species with the strongest east-west (i.e. cross-current) swimming that had net swimming direction significantly different (by the Sign test) from the current.

At the leeward area in the morning, Chromis atripectoralis $(\mathrm{p}=0.02, \mathrm{n}=27)$ and Neopomacentrus cyanomos $(\mathrm{p}=0.05, \mathrm{n}=32)$ swam significantly more toward the reef than the current's direction, and Chrysiptera rollandi swam significantly more away from the reef $(\mathrm{p}=0.05, \mathrm{n}=28)$. In the morning neither Pomacentrus lepidogenys nor Chaetodon plebeius had significant on/offshore directionality relative to current, and the same was true for the 3 pomacentrids for which we had afternoon data.

At the windward area, Chromis atripectoralis swimming direction was significantly more offshore than was the current direction $(\mathrm{p}=0.005, \mathrm{n}=38)$. The other 3 windward species were not significantly more onor offshore than the current in the windward area $(\mathrm{p}>0.10)$.

In Chaetodon atripectoralis net swimming direction did not differ from currents when leeward and windward areas were treated separately $(p=0.10, n=28$ and 43 , respectively). Net swimming for this species did, however, become significantly more offshore than current if data from the 2 areas were pooled $(p=0.02$, $\mathrm{n}=71$ ). In contrast, the pomacentrids differed between areas: they either swam toward the reef in one area and away in the other (Chromis atripectoralis), or had a significant net swimming direction in one area, but not the other (Chrysiptera rollandi and Neopomacentrus cyanomos).

The component of net swimming speed parallel to the current axis might be greater than, less than, or equal to the current speed, indicating, respectively, enhanced, decreased or equivalent dispersal relative to passive behaviour. Chromis atripectoralis consistently decreased dispersal by 4 to $7 \mathrm{~cm} \mathrm{~s}^{-1}$, depending on area and time. This is because it had a strong, consistent southerly component to its swimming; i.e. opposing the mean current. Chaetodon plebeius also decreased dispersal by about $7 \mathrm{~cm} \mathrm{~s}^{-1}$ for the same reason (Table 7).

Two cases of apparently enhanced dispersal were detected by net speed, but both were somewhat dubious. We had appropriate data from only 10 Caesio cuning, so although the $95 \%$ CI of the negative mean net fish speed along the current axis excluded 0 , indicating enhanced dispersal, there were not significantly more negative than positive values (Table 7). For Neopomacentrus cyanomos larvae at the windward area, the apparently enhanced dispersal of about $4 \mathrm{~cm} \mathrm{~s}^{-1}$ was probably due to an interaction between the species' vertical distribution and our current measurement technique. Mean swimming direction of this species was opposite the prevailing current at the windward area, and that should have led to decreased, not enhanced, dispersal. N. cyanomos had the shallowest vertical distribution of any species studied, with a mean depth less than $3 \mathrm{~m}$ (authors' unpubl.), whereas the current-drogue depth was at 5 to $6 \mathrm{~m}$. Surface currents near Lizard Island are faster and more downwind than are currents at $6 \mathrm{~m}$ (Leis 1986), so it seems possible that $N$. cyanomos larvae were swimming in water moving faster to the north than the drogue-tagged water, thus violating the important assumption that the drogue represented movement of the water in which the fish was swimming. The net swimming speed in the direction of the current for the other 3 species did not differ from the current speed (Table 7), nor did speeds of $N$. cyanomos at the leeward area.

\section{DISCUSSION}

The 7 species observed in this study were capable swimmers that, as individuals, overwhelmingly swam in a directional manner and at speeds greater than local currents. Some spatial difference in swimming trajectories was evident, as were some temporal differences. Some species seemed to be using a sun compass

Table 7. Comparison of net fish speed component in the direction of the current, to the current speed, for leeward (lee) and windward areas. Values are the mean differences between the speeds in $\mathrm{cm} \mathrm{s}^{-1}(95 \% \mathrm{CI})$ calculated on a paired basis (positive indicates current speed greater than net fish speed, i.e. fish swam against the current, and negative indicates net fish speed faster than current speed, i.e. fish swam with the current). $p$ is from the 2-tailed Sign test for difference between the 2 speeds; ns: $p>0.10 ; n$ : number of paired current speed and net fish speed observations; $-:$ no data

\begin{tabular}{|lccc|}
\hline Species & \multicolumn{1}{c|}{ Lee am } & Lee $\mathrm{pm}$ & Windward \\
\hline Chromis atripectoralis & $7.1 \pm 4.1, \mathrm{p}=0.02, \mathrm{n}=27$ & $5.7 \pm 3.7, \mathrm{p}=0.05, \mathrm{n}=42$ & $4.3 \pm 4.0, \mathrm{p}=0.05, \mathrm{n}=38$ \\
Chrysiptera rollandi & $2.3 \pm 3.6, \mathrm{~ns}, \mathrm{n}=28$ & - & $1.0 \pm 2.1, \mathrm{~ns}, \mathrm{n}=38$ \\
Neopomacentrus cyanomos & $0.5 \pm 4.3, \mathrm{~ns}, \mathrm{n}=41$ & $1.2 \pm 4.4, \mathrm{~ns}, \mathrm{n}=31$ & $-3.8 \pm 3.2, \mathrm{p}=0.05, \mathrm{n}=32$ \\
Pomacentrus lepidogenys & $-1.3 \pm 3.1, \mathrm{~ns}, \mathrm{n}=38$ & $-1.0 \pm 4.3, \mathrm{~ns}, \mathrm{n}=23$ & - \\
Chaetodon aureofasciatus & $1.4 \pm 4.6, \mathrm{~ns}, \mathrm{n}=28$ & - & $2.2 \pm 3.2, \mathrm{p}=0.10, \mathrm{n}=43$ \\
Chaetodon plebeius & $6.8 \pm 4.4, \mathrm{p}=0.05, \mathrm{n}=20$ & - & - \\
Caesio cuning & $-12.3 \pm 7.9, \mathrm{p}=0.07, \mathrm{n}=10$ & - & - \\
\hline
\end{tabular}


for orientation, whereas others swam in a way that indicates they knew where the island was and were using it for orientation. There was little indication that currents affected swimming direction.

Larvae of the species we studied are unlikely to be exceptional in their abilities to swim and orientate. They were not chosen for any characteristics other than abundance in light-trap catches, and amenability for in situ observation. Their size and development at settlement and pelagic duration range over the lower values of those reported among reef-fish species (references in Table 2). They include species that spawn pelagic eggs and those that spawn demersal eggs, and species with distributions ranging from relatively local (Chaetodon aureofasciatus - Australia to southern New Guinea) to extremely wide (Chromis atripectoralis-Australia to Japan, and Seychelles to Tuamotus).

\section{Swimming speed}

Six of the 7 studied species were 'effective' swimmers that swam faster than local currents in both areas, some up to nearly 3 times as fast. All swam at openwater speeds similar to those reported for them previously (Leis \& Carson-Ewart 1997). The single exception, Chrysiptera rollandi, swam at speeds similar to that of the average current at the leeward area, but about $3 \mathrm{~cm} \mathrm{~s}^{-1}$ less than average currents at the windward area. No within-species differences in swimming speed were found between areas or times, with the exception that Neopomacentrus cyanomos swam 12 to $20 \%$ faster at the leeward than at the windward area. Differences in swimming speed between locations have been reported in other species or situations (Leis \& Carson-Ewart 1999, 2001, 2002) and could have large implications for the ultimate location of the larvae at the end of their pelagic period.

Predictions of cruising speed among species based on size of settlement-stage larvae are likely to be imprecise at best (Leis \& Carson-Ewart 1997). The largest species, Caesio cuning, was indeed the fastest, but the smallest, Chromis atripectoralis, was second fastest. Further, 2 closely related species, Chaetodon plebeius and $C$. aureofasciatus, of very similar in size and morphology, differed in mean speed by about $30 \%$.

\section{Directional variability}

In only 4 of 19 cases (species $\times$ area $\times$ time) was a spatially-dependent difference in variability (expressed as r-values) of the individual trajectories detected. In all 3 cases of distance-related (i.e. on-offshore) differ- ences in variability, the most inshore trajectories were the most variable. In no case was this difference in directional variability found in the same species at both areas, so this brings into question the reality of this apparent pattern. Interpretation of the single between-area (i.e. windward-leeward) difference in variation in directionality was similarly unclear, as only 1 of 4 such comparisons revealed significant differences. In this case, Chromis atripectoralis larvae were more directionally variable in the leeward than in the windward area, but swimming in both areas was still significantly directional, and to the SE.

A higher proportion (3 of 5) of temporal comparisons revealed significant differences in directional variability. Morning trajectories were more variable than afternoon trajectories for 2 of the 3 pomacentrids. In Chromis atripectoralis, afternoon trajectories were more variable under $100 \%$ cloud than under clear skies. This is consistent with other indications (below) that this species uses a sun compass for orientation. It is possible that the morning trajectories of pomacentrids were more variable than those on sunny afternoons because conditions on the mornings when we made observations were more variable (i.e. some observations were made under cloudy or partly cloudy skies), but more work would be required to test this.

\section{Swimming direction and implied cues}

Within area (among distance) differences in swimming direction were uncommon, and the only 2 clear instances of this involved Pomacentrus lepidogenys and Caesio cuning at the leeward area. One possible explanation for this behaviour is that $P$. lepidogenys larvae have a preferred offshore distance from the reef: $1000 \mathrm{~m}$ is too far offshore, so the larvae swim shoreward, whereas $<500 \mathrm{~m}$ is too close, so the larvae swim offshore. This is consistent with previous studies showing pomacentrid larvae to be more abundant nearshore than offshore (Leis \& McCormick 2002). Larvae of $P$. lepidogenys swim at ca. $15 \mathrm{~cm} \mathrm{~s}^{-1}$, so could reach the reef within $1 \mathrm{~h}$ from $500 \mathrm{~m}$. A preferred distance suggests that $P$. lepidogenys can detect not only the bearing, but also the distance, to the nearest reef, a suggestion that requires further study. The differences in swimming direction among distances in C. cuning should be treated cautiously, given the few individuals of this species that we studied.

Windward-leeward comparisons revealed speciesspecific differences in swimming direction among the 4 species examined. One species swam offshore in both areas, 1 swam onshore at the leeward area and approximately parallel to shore on the windward, 1 swam SE at both areas, and 1 had no directionality at either area. 
The swimming patterns of the pomacentrids suggest solar compass orientation, but those of the chaetodontids do not. Morning-afternoon comparisons of pomacentrids (all at the leeward area) revealed that swimming was more westerly in the afternoon than in the morning (albeit 1 was not significantly more westerly). This, plus the observation that afternoon trajectories of C. atripectoralis were more variable both within individuals and among individuals under conditions of full cloud than under sunny conditions, all imply that these pomacentrids were utilizing a sun compass orientation. Further work to specifically assess this indication is warranted. In contrast, the offshore swimming of the butterflyfish larvae strongly suggests that they knew where the island was, and used a reef-based cue to orientate their swimming.

An earlier study off Lizard Island during the day (Leis et al. 1996) concluded that the average swimming direction of a group of 30 species was offshore. In the present study based on a different data set we detected a more complex picture because we concentrated on fewer species, enabling sufficient replication so that patterns of individual species could be determined. We found strong differences among species, but also apparent family-level patterns of orientation. Pomacentrids seemingly used sun-compass orientation, apparently without regard to the position of the reef (except Pomacentrus lepidogenys) and chaetodontids swam offshore from the reef. Even within families, species differed in among-individual variation in swimming direction, and in the directions they swam. Chromis atripectoralis was the least variable pomacentrid, whereas Chrysiptera rollandi was the most variable, and Chaetodon atripectoralis was more variable than was $C$. plebeius.

If solar cues were used for orientation by larval pomacentrids, several implications arise. First, orientation should be both less precise and less accurate under cloudy conditions. These frequently arise during the spawning season on the Great Barrier Reef as it is also the rainy season, and cyclones are not infrequent. Thus, meteorological conditions might have an effect on settlement intensity or locality, but we are unaware of any studies that have addressed this possibility. Solar cues would be useful over broad spatial scales. For example, they could assist larvae in the Coral Sea to swim to the west and thereby find settlement sites on the Great Barrier Reefs. Use of a solar cue would not necessarily assist in locating a particular reef, and would be independent of the distance from or bearing to any reef. Stobutzki \& Bellwood (1998) found that pomacentrid larvae swam toward Lizard Island at night, implicating a reef-based cue. So, different cues may be used at night to during the day. Sun-compass orientation has been shown or inferred for marine jellyfishes (Shanks \& Graham 1987, Hamner et al. 1994) and larval crabs (Shanks 1995), but not previously for larval reef fishes.

The use of reef-based cues also has implications, although at present, identification of the cues is speculative. In at least 3 of the species studied, there was evidence of remote detection of the Lizard Island reefs presumably by reef-based cues. The 2 species of chaetodontid larvae did not vary in swimming direction with distance offshore, as might be expected if using some reef-based cues (e.g. reef odour), but they did have more variable swimming trajectories when closest to the reefs. We speculate that they were searching for the near-by reef or shifting from using a cue suited to long-distance orientation, to another suited to short distances (e.g. Kingsford et al. 2002, Myrberg \& Fuiman 2002). In contrast, Pomacentrus lepidogenys swam toward the reef when furthest from it, but not when closer, implying a distance-dependent response to a reef-based cue. The sensory abilities of these 3 species remain unstudied. At least some pomacentrid larvae hear reef sounds and use them for navigation (Leis et al. 2002 \& unpubl.), and some pomacentrid larvae use olfactory cues over small scales to find settlement habitat (reviewed in Leis \& McCormick 2002). Nothing is known about sensory abilities in chaetodontid larvae, although what appear to be morphological specializations for hearing are present in some species (Webb 1998, Webb \& Smith 2000). Whatever cues were used obviously operate over scales of at least $1 \mathrm{~km}$, and should be useful in locating individual reefs. The distance-specific swimming directions found in Caesio cuning also are an indication of an ability to detect reef cues, but we only made observations on few individuals, so any interpretations must be suspect. Orientation of fish larvae using reef-based cues has been shown or inferred by several studies (e.g. Montgomery et al. 2001, Leis \& McCormick 2002).

Temporally- or spatially-dependent differences in behaviour that we document here in swimming direction and speed, and in directional variability, mean that realistic modelling of dispersal by reef-fish larvae will be a complex challenge. We found differences in behaviour that can influence dispersal trajectories among species, between morning and afternoon, between sunny and cloudy periods, among distances 0.1 to $1 \mathrm{~km}$ apart in an area, and between areas a few $\mathrm{km}$ apart. Our observations were made during the day, and it is likely that behaviour differs at night. Therefore it is clear that recent welcome attempts to include behaviour of larvae in dispersal models (e.g. Wolanski et al. 1997, Porch 1998, Armsworth 2000) will have to include considerably more behavioural complexity if the goal is realism. Only when we understand what causes these differences will it be possible for mod- 
ellers to adequately incorporate behaviour of larvae into their dispersal models.

A few of the larvae released $100 \mathrm{~m}$ from the reef edge reached the reef, and we consider that they encountered the reefs because of their pelagic swimming direction rather than by reef-seeking behaviour per se. At the leeward area in the morning, 7 individuals reached the reef during the 10 min observation period: 6 were Chromis atripectoralis which had a strong onshore swimming direction (SE) in the morning. A single Pomacentrus lepidogenys also reached the reef edge. The 3 species released in the afternoon had more westerly trajectories, and no larvae reached the reef. Of the 4 species released near the windward reef, none crossed onto the reef, and only 2 Neopomacentrus cyanomos came within view of it (both turned away offshore). None of these 4 species had onshore average windward trajectories.

\section{Interaction of current and swimming}

Our observations gave little indication that current direction influenced swimming direction. However, due to the distribution of current directions (bimodal and strongly to the north) few individuals were observed under southerly currents. We would not expect larval fish swimming to be influenced by currents because a pelagic animal cannot detect currents (other than those created by its own swimming) without an outside reference (Montgomery et al. 2001, Leis \& McCormick 2002). No fish larvae are known to be able to detect outside reference cues (e.g. magnetic fields), but much remains unknown about sensory abilities of larval reef fishes (Leis et al. 1996, Kingsford et al. 2002).

All 7 species studied here are capable of orientated swimming, at least at the individual level, and in most cases at a population level, at speeds faster than local currents. This implies that they have much control over their position. However, their through-water trajectories must be combined with water movement to determine their net trajectories relative to the bottom or to reefs. Although the net swimming directions and speeds were less accurate than the through-water measurements, they are arguably more relevant to the question of finding reefs and reaching them. The predominantly northerly currents greatly influenced net swimming speeds and directions. Most net swimming directions were more nearly onshore-offshore than were swimming directions through the water because the currents in part cancelled the common southerly component of the swimming trajectories, leaving a predominant east-west (on-offshore) component.

At least 6 of the 7 studied species provided indications that behaviour resulted in net movement different from passive drift with currents. Chromis atripectoralis was the most consistent, because it differed from average current direction, it moved more on-shore or offshore than current, and it decreased dispersal by about half of average current speed. Chaetodon plebeius differed from average current direction and decreased dispersal by about the same as C. atripectoralis. Chaetodon aureofasciatus moved more offshore than did currents (if data from both areas were pooled). Caesio cuning may have enhanced dispersal by swimming in the direction of the current, but low numbers of individuals observed made this result equivocal. Neopomacentrus cyanomos moved more onshore than did currents, but only in the morning at the leeward area, and may have augmented dispersal at the windward area. Finally, Chrysiptera rollandi moved more offshore than currents, but only at the leeward area. There was no indication that behaviour affected net movement in $\mathrm{Po}$ macentrus lepidogenys, but this species had distancespecific swimming directions that would alter currentderived trajectories at some locations. It has been argued that settlement-stage reef-fish larvae have swimming and sensory capabilities that should enable control over trajectories and alter them from passive drift with currents (Leis \& Carson-Ewart 1997, Stobutzki \& Bellwood 1997, Leis \& McCormick 2002), but deviation from passive drift has not been demonstrated previously in settlement-stage reef-fish larvae.

Our results do not suggest that individual larvae can detect and respond to currents in the pelagic environment resulting in trajectories that differ from passive drift. Rather, it is likely that the behaviour was a response to the presence of the Lizard Island reefs, the position of the sun, or perhaps a genetically determined tendency to swim against the average currents of the area, using a solar compass to achieve this.

The average behaviour of a species can be misleading with respect to population demographics and zoogeography. For example, a species may appear to have current-controlled passive dispersal (i.e. acceptance of the null hypothesis), when, in fact, roughly equal numbers of individuals, enhance, decrease, or do not alter current-based dispersal. In such a species, roughly equal numbers may self-recruit to the natal population, recruit to a population very far downstream, and recruit to where the currents take them. For this reason, it is useful to consider not only average behaviours, but also extreme behaviours when modelling dispersal.

\section{CONCLUSIONS}

We found that late-stage larvae of 7 coral-reef fishes of 3 families had a well-developed ability to orientate 
in the pelagic environment, to swim non-randomly, and to swim faster than local currents. They not only had the ability to alter their dispersal from that expected from passive drift, but most actually did so. Settlement-stage larvae have the swimming endurance (Stobutzki \& Bellwood 1997, Fisher et al. 2000, Fisher \& Bellwood 2002) to maintain such behaviour for extended periods, thus providing impressive capabilities for controlling their own dispersal and, ultimately, settlement. Orientation and swimming varied, depending on species, over spatial scales of 100s of $\mathrm{m}$ to several $\mathrm{km}$ and at different times of the day. When orientating in the pelagic environment, larvae of pomacentrids seemed to be responding to solar cues, whereas larvae of chaetodontids, 1 of the pomacentrids and perhaps a lutjanid seemed to be responding to reef-based cue(s). All these behaviours and variations in them have implications for dispersal, population connectivity and attempts to model them. At about the time of settlement, larval reef fishes are clearly not planktonic. We must now determine when during the pelagic phase these behavioural abilities begin to come into play, how these abilities differ among species, and how behaviour at night differs from what we have documented during the day.

Acknowledgements. Support by ARC grants A19530997 and A19804335 to J.M.L. and by the Australian Museum is gratefully acknowledged. For making this work possible, we thank the staff of the Lizard Island Research Station, and those who helped in the field, including D. Annise, D. Bray, T. Compton, T. Dempster, M. Emslie, A. Hay, R. Kelley, T. Lemberget, D. Priddle, U. Siebeck and T. Trnski. A. R. Jones provided statistical advice. P. Ovenden provided the photographs in Fig. 2. S. Bullock made up Fig. 2, and along with A. C. Hay provided editorial assistance. A. L. Shanks and L. A. Fuiman constructively criticised the manuscript.

\section{LITERATURE CITED}

Allen GR (1991) Damselfishes of the world. Mergus Publishers, Melle

Allen G, Steene R, Allen M (1998) A guide to angelfishes and butterflyfishes. Odessey Publishing, Perth

Armsworth PR (2000) Modelling the swimming response of late stage larval reef fish to different stimuli. Mar Ecol Prog Ser 195:231-247

Bainbridge R (1952) Underwater observations on the swimming of marine zooplankton. J Mar Biol Assoc UK 31:107-112

Batschelet E (1981) Circular statistics in biology. Academic Press, London

Carpenter KE (1987) Revision of the Indo-Pacific fish family Caesionidae (Lutjanoidea), with descriptions of five new species. Indo-Pac Fish 15:1-56

Elliott JK, Elliott JM, Mariscal RN (1995) Host selection, location, and association behaviours of anemonefishes in field selection experiments. Mar Biol 122:377-389

Fisher R, Bellwood DR (2002) The influence of swimming speed on the sustained swimming performance of latestage reef fish larvae. Mar Biol 140:801-807
Fisher R, Bellwood DR, Job SD (2000) Development of swimming abilities in reef fish larvae. Mar Ecol Prog Ser 202: 163-173

Frith CA, Leis JM, Goldman B (1986) Currents in the Lizard Island region of the Great Barrier Reef Lagoon and their relevance to potential movements of larvae. Coral Reefs 5: 81-92

Hamner WM, Hamner PP, Strand SW (1994) Sun-compass migration by Aurelia aurita (Scyphozoa): population retention and reproduction in Saanich Inlet, British Columbia. Mar Biol 119:347-356

Jones GP, Milicich MJ, Emslie MJ, Lunow C (1999) Selfrecruitment in a coral reef fish population. Nature 402 : 802-804

Kingsford MJ, Leis JM, Shanks A, Lindeman K, Morgan S, Pineda J (2002) Sensory environments, larval abilities and local self-recruitment. Bull Mar Sci 49:309-340

Leis JM (1986) Vertical and horizontal distribution of fish larvae near coral reefs at Lizard Island, Great Barrier Reef. Mar Biol 90:505-516

Leis JM (1989) Larval biology of butterflyfishes (Pisces, Chaetodontidae): what do we really know? Environ Biol Fish 25:87-100

Leis JM (2002) Pacific coral-reef fishes: the implications of behaviour and ecology of larvae for biodiversity and conservation, and a reassessment of the open population paradigm. Environ Biol Fish 65:199-208

Leis JM, Carson-Ewart BM (1997) Swimming speeds of the late larvae of some coral reef fishes. Mar Ecol Prog Ser 159:165-174

Leis JM, Carson-Ewart BM (1998) Complex behaviour by coral-reef fish larvae in open-water and near-reef pelagic environments. Environ Biol Fish 53:259-266

Leis JM, Carson-Ewart BM (1999) In situ swimming and settlement behaviour of larvae of an Indo-Pacific coral-reef fish, the coral trout (Pisces, Serranidae, Plectropomus leopardus). Mar Biol 134:51-64

Leis JM, Carson-Ewart BM (eds) (2000) The larvae of Indo-Pacific coastal fishes: a guide to identification. Brill, Leiden

Leis JM, Carson-Ewart BM (2001) Behavioural differences in pelagic larvae of four species of coral-reef fishes between two environments: ocean and atoll lagoon. Coral Reefs 19: 247-257

Leis JM, Carson-Ewart BM (2002) In situ settlement behaviour of damselfish larvae (Pomacentridae). J Fish Biol 61: 325-346

Leis JM, McCormick MI (2002) The biology, behaviour and ecology of the pelagic, larval stage of coral-reef fishes. In: Sale PF (ed) Coral reef fishes: new insights into their ecology. Academic Press, San Diego, p 171-199

Leis JM, Stobutzki IC (1999) Swimming performance of late pelagic larvae of coral-reef fishes: in situ and laboratorybased measurements. In: Seret B, Sire JY (eds) Proc 5th Indo-Pacific Fish Conf, Noumea 1997. Soc Franc Ichthyol \& Inst Rech Develop, Paris, p 575-583

Leis JM, Sweatman HPA, Reader SE (1996) What the pelagic stages of coral reef fishes are doing out in blue water: daytime field observations of larval behaviour. Mar Freshw Res 47:401-411

Leis JM, Carson-Ewart BM, Cato DH (2002) Sound detection in situ by the larvae of a coral-reef damselfish (Pomacentridae). Mar Ecol Prog Ser 232:259-268

Montgomery JC, Tolimieri N, Haine OS (2001) Active habitat selection by pre-settlement reef fishes. Fish Fisheries 2: 261-277

Myrberg AA, Fuiman LA (2002) The sensory world of coral 
reef fishes. In: Sale PF (ed) Coral reef fishes: new insights into their ecology. Academic Press, San Diego, p 123-148

Ninos M (1984) Settlement and metamorphosis in Hypsoblennius (Pisces, Blenniidae). Unpubl. PhD thesis, University of Southern California, Los Angeles

Ogden JC, Quinn TP (1984) Migration in coral reef fishes: ecological significance and orientation mechanisms. In: McCleave JD, Arnold GP, Dodson JJ, Neill WH (eds) Mechanisms of migration in fishes. Plenum Press, New York, p 293-308

Porch CE (1998) A numerical study of larval fish retention along the southeast Florida coast. Ecol Model 109:35-59

Quinn TP, Ogden JC (1984) Field evidence of compass orientation in migrating juvenile grunts (Haemulidae). J Exp Mar Biol Ecol 81:181-192

Roberts CM (1997) Connectivity and management of Caribbean coral reefs. Science 278:1454-1456

Shanks AL (1995) Orientated swimming by megalopae of several eastern North Pacific crab species and its potential role in their onshore migration. J Exp Mar Biol Ecol 186: $1-16$

Shanks AL, Graham WM (1987) Orientated swimming in the jellyfish Stomolopus meleagris L. Agassiz (Scyphozoan: Rhizostomida). J Exp Mar Biol Ecol 108:159-169

Sponaugle S, Cowen RK, Shanks A, Morgan SG and 7 others (2002) Predicting self-recruitment in marine populations: biophysical correlates. Bull Mar Sci 49:341-375

Stobutzki IC, Bellwood DR (1997) Sustained swimming abilities of the late pelagic stages of coral reef fishes. Mar Ecol Prog Ser 149:35-41

Editorial responsibility: Charles Birkeland

(Contributing Editor), Honolulu, Hawaii, USA
Stobutzki IC, Bellwood DR (1998) Nocturnal orientation to reefs by late pelagic stage coral reef fishes. Coral Reefs 17 : 103-110

Swearer SE, Caselle JE, Lea DW, Warner RR (1999) Larval retention and recruitment in an island population of a coral-reef fish. Nature 402:799-802

Sweatman HPA (1988) Field evidence that settling coral reef fish larvae detect resident fishes using dissolved chemical cues. J Exp Mar Biol Ecol 124:163-174

Thresher RE, Colin PL, Bell LJ (1989) Planktonic duration, distribution and population structure of western and central Pacific damselfishes (Pomacentridae). Copeia 1989: $420-434$

Webb JF (1998) Laterophysic connection: a unique link between swimbladder and the lateral line system in Chaetodon (Perciformes: Chaetodontidae). Copeia 1998: 1032-1036

Webb JF, Smith WL (2000) The laterophysic connection in chaetodontid butterflyfish: morphological variation and speculations on sensory function. Phil Trans R Soc Lond B 355:1125-1129

Wellington GM, Victor BC (1989) Planktonic larval duration of one hundred species of Pacific and Atlantic damselfishes (Pomacentridae). Mar Biol 101:557-567

Wolanski E, Doherty PJ, Carelton J (1997) Directional swimming of fish larvae determines connectivity of fish populations on the Great Barrier Reef. Naturwissenschaften 84: $262-268$

Zar JH (1996) Biostatistical analysis, 3rd edn. Prentice-Hall, Upper Saddle River, NJ

Submitted: July 17, 2002; Accepted: January 8, 2003

Proofs received from author(s): April 7, 2003 